\title{
Assessment of Arsenic and Fluoride in Ground Waters of Sedam and Shahabad Regions of Gulbarga District
}

\author{
Meenakshi K. C. and Shashikanth H. Majagi \\ Government College, Sedam Road, Kalaburagi-585106, Karnataka-India \\ Email: smajgi@rediffmail.com
}

\begin{abstract}
The present study has been carried out to assess arsenic and fluoride concentration in groundwater from June 2014 to May 2015. Every month water samples were collected and analyzed according to APHA. All the Physico-chemical parameters of the groundwater of study area are within the permissible limit. Heavy metal analysis was carried out through AAS. Data is subjected for statistical analysis.
\end{abstract}

KeyWords: Kalaburagi, physico-chemical, heavy metals, groundwater, India.

\section{Introduction}

Arsenic ranks $20^{\text {th }}$ in abundance among the elements in the earth crust. Arsenic is introduced into environment from the natural sources (e.g. volcanic activity and weathering of minerals) and from anthropogenic activity (e.g. oar smelting, burning if coal, pesticide use) and the ratio between the two type of sources has been estimated at 60:40(1). Levels and speciation of arsenic in drinking water (including natural mineral and other bottled water) is a matter of concern in many countries as arsenic level exceeding $200 \mathrm{mg} / \mathrm{l}$ have been reported (6). Several reports in the literature of similar or even higher arsenic concentration level in well and in ground water reflects this problem.

The most toxic forms of arsenic food and water are inorganic (III) and (V) (9). And the International Agency for Research for Cancer (IARC) has classified in organic arsenic a human carcinogen. (10). The inorganic arsenic trioxide has a well known history as a poisonous compound often used in the cases of homicide.

The provisional tolerable daily intake of inorganic via food and water was established by WHO at 2 $\mathrm{\mu g} / \mathrm{kg}$ body weight in 1983(14). And later changed to the equivalent provisional tolerable week intake (PTWI) at $15 \mathrm{\mu g} / \mathrm{kg}$ body weight in 1988 (15). The epidemiological data used for this risk assessment refer too inorganic arsenic in drinking water. However, a similar recommendation for organic arsenic species in food could not be established by WHO due to lack of appropriate toxicological data. This recommendation has been repeated and substantiated by the US agency for toxic substance and disease registry (16). The recommended WHO guidelines level for inorganic in drinking water is $10 \mu \mathrm{g} / \mathrm{l}(17)$ and according to these guidelines $20 \%$ of the PTWI is allocated to drinking water.

In contrast to its toxicity, the possible essential role of arsenic (18) is a matter of controversy (19). The underlying animal experiments, however, do not allow for any conclusions regarding a possible essential function of arsenic to human.

Epidemiological studies have shown human health effects after long term oral exposure to inorganic arsenic species in drinking water from wells in areas where the soil is geochemically rich in arsenic. The long term daily intake of organic at $10-50 \mu \mathrm{g} / \mathrm{kg}$ body weight contributed to vascular problems which may ultimately lead to necrosis and gangrene of hands and feet. (Black foot disease) (16). The united states Environmental protection Agency (USEPA) has estimated the excess skin cancer risk from lifetime exposure to arsenic via water (21) containing $1 \mathrm{\mu g} / \mathrm{l}$ of inorganic arsenic at $7 \mathrm{X} 10-5$. Therefore drinking water concentration of arsenic exceeding this level is a matter of concern. At the $10 \mu \mathrm{g} / \mathrm{l} \mathrm{WHO}$ guidelines level of arsenic in drinking water, the estimated lifetime risk for arsenic induced skin cancer has been estimated (17) at 6x10-4.

Arsenic is introduced into soil and groundwater during weathering of rocks and minerals followed by subsequent leading and runoff. It can also be introduced into soil and groundwater from anthropogenic sources. Many factors control arsenic concentration and transport in groundwater which include Redox 
potential (Eh), adsorption/desorption, precipitation/dissolution, Arsenic speciation, pH presence and concentration of competing ions biological transformation etc.

Therefore, rigorous geochemical investigation for adequate understanding of arsenic geochemistry under different hydro-geological and geo-environmental conditions of aquifers is essentially required for evolving sustaining solution.

Fluoride is the $13^{\text {th }}$ most abundant element on earth. It cannot exist outside a controlled environment without combining with outer substance to become fluoride. Three main anthropogenic sources were identified as fertilizers, combusted coal and industrial waste with phosphate fertilizer being the most significant source of fluoride. 13. There are ionizable, non-ionizable organic and inorganic fluoride. Fluoride is probably an essential element for animals and humans. Low concentration provides protection against dental caries, especially children. Minimum concentration of fluoride in drinking water required to produce protective effect is approximately $0.5 \mu \mathrm{g} / \mathrm{l}$.

\section{Methodology}

Gulbarga district lies in the northern plains of Karnataka state, which covers an area of $16244 \mathrm{sq} . \mathrm{km}$. and lies between $16^{0}-11^{\prime}$ and $17^{0}-19^{\prime} \mathrm{N}$ latitude and 76-54' E longitude, with average rainfall of 35-56 $\mathrm{mm}$ and maximum and minimum temperature being $45{ }^{\circ} \mathrm{C}$ and $12{ }^{0} \mathrm{C}$ respectively. NEM, SWM and summer seasons of 12 months. These water samples collected were subjected to chemical analysis as per standard methods (APHA, 1989) and other physical-chemical parameters and statistical analysis of the data presented.

The samples one liter were filtered in the laboratory and preserved by adding $5 \mathrm{ml}$ of concentration HNO3 by which pH was lowered to 1-2 preserved samples were determined by using AAS (iCE3XXXCO93300198Vl.30). The procedure followed to analyze the heavy metals concentrations were taken from standard methods (APHA).

\section{Objectives and Study Area}

1. To analyze the physic-chemical characteristic of water sample with special emphasis on fluoride and arsenic contents.

2. To assess the suitability of water for human consumption and irrigation.

3. To find out the sources of pollution.

4. To create awareness about health hazards from fluoride and arsenic content in drinking water.

5. Analysis of heavy metals in the groundwater and surface water.

The study areas are two regions of Gulbarga District. One Sedam is taluk head quarter which falls under $17.1784^{\circ} \mathrm{N}$ and $77.2873^{\circ} \mathrm{E}$ which is $80 \mathrm{~km}$ away from Gulbarga city and Shahabad falls under 17.130318 N Latitude and 76.943504 E Longitude $30 \mathrm{~km}$ away for Gulbarga city.

\section{$4 \quad$ Results}

Table 1. Monthly average values of four bore wells physico-chemical parameters of sedam station 1

\begin{tabular}{l|l|l|l|l|l|l|l|l|l|l|l|l}
\hline $\begin{array}{l}\text { Month/ } \\
\text { Parameters }\end{array}$ & $\begin{array}{l}\text { At. } \\
\text { Temp. }\end{array}$ & $\begin{array}{l}\text { Water. } \\
\text { Temp. }\end{array}$ & PH & DO & $\begin{array}{l}\text { Total } \\
\text { Hardness }\end{array}$ & Ca & Mg & Chloride & Alkalinity & NO3 & PO4 & Fluoride \\
\hline June-2014 & 32 & 22 & 7.1 & 2.1 & 480 & 254 & 192 & 400 & 350 & 67 & 0.78 & 1.2 \\
\hline July & 31 & 22 & 7.1 & 2.1 & 496 & 260 & 202 & 426 & 355 & 65 & 0.76 & 1.3 \\
\hline August & 30 & 22 & 7.1 & 2.2 & 550 & 282 & 156 & 446 & 380 & 85 & 0.82 & 1.4 \\
\hline September & 30 & 22 & 7.1 & 2.3 & 572 & 264 & 152 & 452 & 365 & 68 & 0.83 & 1.5 \\
\hline October & 29 & 22 & 7.2 & 2.4 & 590 & 322 & 186 & 496 & 425 & 78 & 0.95 & 1.6 \\
\hline November & 28 & 22 & 7.2 & 2.3 & 628 & 312 & 198 & 398 & 415 & 72 & 1.0 & 1.4 \\
\hline December & 26 & 22 & 7.3 & 2.3 & 652 & 356 & 212 & 345 & 425 & 88 & 1.12 & 1.3 \\
\hline January-2015 & 27 & 22 & 7.1 & 2.1 & 644 & 352 & 202 & 386 & 420 & 70 & 1.15 & 1.4 \\
\hline
\end{tabular}




\begin{tabular}{l|l|l|l|l|l|l|l|l|l|l|l|l}
\hline February & 33 & 23 & 7.1 & 2.0 & 610 & 304 & 188 & 389 & 335 & 66 & 0.62 & 1.1 \\
\hline March & 37 & 22 & 7.1 & 1.8 & 482 & 298 & 183 & 402 & 310 & 54 & 0.60 & 1.1 \\
\hline April & 38 & 23 & 7.1 & 1.9 & 480 & 286 & 192 & 363 & 325 & 52 & 0.63 & 1.1 \\
\hline May & 39 & 23 & 7.1 & 1.8 & 496 & 244 & 182 & 365 & 285 & 50 & 0.62 & 1.2 \\
\hline
\end{tabular}

Table 2. Seasonal average values of arsenic and other heavy metals parameters of sedam station 1.

\begin{tabular}{l|l|l|l|l|l|l|l|l|l|l|l}
\hline Seasons/Heavy metals & $\mathrm{Cu}$ & $\mathrm{Fe}$ & $\mathrm{Zn}$ & $\mathrm{Mn}$ & $\mathrm{Cd}$ & $\mathrm{Si}$ & $\mathrm{V}$ & $\mathrm{Ti}$ & $\mathrm{Cr}$ & $\mathrm{Mo}$ & $\mathrm{As}$ \\
\hline SWM & 0.078 & 0.2 & 0.018 & 0.05 & 0.030 & 7.18 & 0.28 & 2.52 & 0.12 & 0.152 & 0.211 \\
\hline NEM & 0.009 & 0.21 & 0.18 & 0.07 & 0.076 & 6.98 & 0.72 & 2.02 & 0.11 & 0.192 & 0.22 \\
\hline SUMMER & 0.007 & 0.21 & 0.036 & 0.09 & 0.072 & 9.12 & 0.86 & 2.10 & 0.13 & 0.210 & 0.23 \\
\hline
\end{tabular}

Table 3. Monthly average values of four bore wells physico-chemical parameters of sedam station 2 .

\begin{tabular}{l|l|l|l|l|l|l|l|l|l|l|l|l}
\hline $\begin{array}{l}\text { Month/ } \\
\text { Parameters }\end{array}$ & $\begin{array}{l}\text { At. } \\
\text { Temp. }\end{array}$ & $\begin{array}{l}\text { Water } \\
\text { Temp. }\end{array}$ & PH & DO & $\begin{array}{l}\text { Total } \\
\text { Hardness }\end{array}$ & Ca & Mg. & Chloride & Alkalinity & NO3 & PO4 & Fluoride \\
\hline June -2014 & 32 & 22 & 7.1 & 2.4 & 510 & 192 & 110 & 380 & 295 & 78 & 0.82 & 0.12 \\
\hline July & 31 & 22 & 7.2 & 2.4 & 546 & 186 & 132 & 376 & 310 & 62 & 0.78 & 0.98 \\
\hline August & 30 & 22 & 7.2 & 2.3 & 562 & 232 & 136 & 356 & 305 & 58 & 0.82 & 0.96 \\
\hline September & 30 & 22 & 7.3 & 2.5 & 568 & 244 & 138 & 350 & 355 & 62 & 0.86 & 1.6 \\
\hline October & 29 & 22 & 7.3 & 2.6 & 620 & 258 & 150 & 450 & 375 & 78 & 0.96 & 1.42 \\
\hline November & 28 & 22 & 7.3 & 2.5 & 610 & 286 & 148 & 456 & 365 & 72 & 0.98 & 1.58 \\
\hline December & 26 & 22 & 7.3 & 2.5 & 598 & 268 & 132 & 396 & 350 & 86 & 0.92 & 1.66 \\
\hline January-2015 & 27 & 22 & 7.3 & 2.4 & 572 & 222 & 102 & 390 & 355 & 98 & 1.12 & 1.52 \\
\hline February & 33 & 22 & 7.4 & 2.2 & 510 & 232 & 108 & 320 & 330 & 96 & 1.02 & 0.9 \\
\hline March & 37 & 23 & 7.3 & 2.1 & 566 & 208 & 98 & 356 & 315 & 88 & 68 & 0.9 \\
\hline April & 38 & 23 & 7.4 & 2.1 & 570 & 210 & 92 & 348 & 310 & 74 & 72 & 0.9 \\
\hline May & 39 & 24 & 7.4 & 2.2 & 532 & 212 & 102 & 338 & 310 & 72 & 76 & 0.8 \\
\hline
\end{tabular}

Table 4. Seasonal average values of arsenic and other heavy metals parameters of sedam station 2.

\begin{tabular}{l|l|l|l|l|l|l|l|l|l|l|l}
\hline Seasons/Heavy metals & $\mathrm{Cu}$ & $\mathrm{Fe}$ & $\mathrm{Zn}$ & $\mathrm{Mn}$ & $\mathrm{Cd}$ & $\mathrm{Si}$ & $\mathrm{V}$ & $\mathrm{Ti}$ & $\mathrm{Cr}$ & $\mathrm{Mo}$ & $\mathrm{As}$ \\
\hline SWM & 0.088 & 0.21 & 0.020 & 0.09 & 0.042 & 8.12 & 0.32 & 3.32 & 0.18 & 0.16 & 0.32 \\
\hline NEM & 0.092 & 0.232 & 0.019 & 0.08 & 0.092 & 7.92 & 0.56 & 3.15 & 0.19 & 0.18 & 0.29 \\
\hline SUMMER & 0.008 & 0.23 & 0.036 & 0.09 & 0.12 & 8.12 & 0.88 & 2.90 & 0.21 & 0.20 & 0.31 \\
\hline
\end{tabular}

Table 5. Monthly average values of physico-chemical parameters of shahabad station 1

\begin{tabular}{l|l|l|l|l|l|l|l|l|l|l|l|l}
\hline $\begin{array}{l}\text { Month/ } \\
\text { Parameters }\end{array}$ & $\begin{array}{l}\text { At. } \\
\text { Temp. }\end{array}$ & $\begin{array}{l}\text { Water } \\
\text { Temp. }\end{array}$ & $\mathrm{pH}$ & $\mathrm{DO}$ & $\begin{array}{l}\text { Total } \\
\text { Hardness }\end{array}$ & Ca & Mg. & Chloride & Alkalinity & NO3 & PO4 & Fluoride \\
\hline June -2014 & 32 & 22 & 7.9 & 2.5 & 660 & 302 & 169 & 335 & 310 & 78 & 0.7 & 1.5 \\
\hline July & 32 & 23 & 7.4 & 2.6 & 680 & 272 & 157 & 310 & 325 & 58 & 0.9 & 1.6 \\
\hline August & 33 & 22 & 7.3 & 2.5 & 696 & 296 & 180 & 320 & 355 & 56 & 0.92 & 1.5 \\
\hline September & 26 & 22 & 7.4 & 2.6 & 710 & 318 & 200 & 365 & 435 & 85 & 0.92 & 1.7 \\
\hline October & 30 & 22 & 7.4 & 2.8 & 738 & 350 & 212 & 385 & 425 & 96 & 1.4 & 1.7 \\
\hline November & 29 & 21 & 7.4 & 2.8 & 750 & 366 & 210 & 360 & 465 & 88 & 1.62 & 1.8 \\
\hline December & 31 & 21 & 7.3 & 2.8 & 815 & 354 & 212 & 355 & 495 & 78 & 1.58 & 1.9 \\
\hline January-2015 & 32 & 22 & 7.3 & 2.8 & 802 & 332 & 214 & 355 & 450 & 110 & 1.68 & 1.8 \\
\hline February & 33 & 23 & 7.4 & 2.8 & 762 & 312 & 126 & 320 & 430 & 102 & 1.52 & 1.8 \\
\hline
\end{tabular}




\begin{tabular}{l|l|l|l|l|l|l|l|l|l|l|l|l}
\hline April & 37 & 23 & 7.4 & 2.2 & 610 & 298 & 144 & 235 & 360 & 92 & 0.9 & 1.6 \\
\hline May & 39 & 23 & 7.4 & 2.3 & 650 & 272 & 123 & 215 & 350 & 86 & 0.8 & 1.5 \\
\hline
\end{tabular}

Table 6. Seasonal average values of arsenic and other heavy metals parameters of shahabad - station 1.

\begin{tabular}{l|l|l|l|l|l|l|l|l|l|l|l}
\hline Seasons/Heavy metals & $\mathrm{Cu}$ & $\mathrm{Fe}$ & $\mathrm{Zn}$ & $\mathrm{Mn}$ & $\mathrm{Cd}$ & $\mathrm{Si}$ & $\mathrm{V}$ & $\mathrm{Ti}$ & $\mathrm{Cr}$ & $\mathrm{Mo}$ & $\mathrm{As}$ \\
\hline SWM & 0.0054 & 0.125 & 0.014 & 0.022 & 0.019 & 22.3 & 0.611 & 1.446 & 0.084 & 0.156 & 0.237 \\
\hline NEM & 0.0062 & 0.152 & 0.021 & 0.028 & 0.022 & 25.5 & 0.696 & 1.565 & 0.089 & 0.168 & 0.288 \\
\hline SUMMER & 0.0071 & 0.182 & 0.039 & 0.036 & 0.028 & 35.6 & 0.824 & 1.889 & 0.098 & 0.201 & 0.356 \\
\hline
\end{tabular}

Table 7. Monthly average values of physico-chemical parameters of shahabad station 2

\begin{tabular}{l|l|l|l|l|l|l|l|l|l|l|l|l}
\hline $\begin{array}{l}\text { Month/ } \\
\text { Parameters }\end{array}$ & $\begin{array}{l}\text { At. } \\
\text { Temp. }\end{array}$ & $\begin{array}{l}\text { Water } \\
\text { Temp. }\end{array}$ & $\mathrm{pH}$ & $\mathrm{DO}$ & $\begin{array}{l}\text { Total } \\
\text { Hardness }\end{array}$ & Ca & Mg. & Chloride & Alkalinity & NO3 & PO4 & Fluoride \\
\hline June-2014 & 32 & 21 & 7.6 & 2.6 & 552 & 186 & 124 & 285 & 265 & 66 & 096 & 1.6 \\
\hline July & 32 & 21 & 7.5 & 2.6 & 574 & 250 & 112 & 295 & 285 & 62 & 0.86 & 1.8 \\
\hline August & 33 & 22 & 7.5 & 2.7 & 598 & 236 & 120 & 280 & 305 & 62 & 0.72 & 1.9 \\
\hline September & 26 & 22 & 7.4 & 2.6 & 642 & 296 & 122 & 305 & 315 & 72 & 0.68 & 1.6 \\
\hline October & 30 & 23 & 7.5 & 2.5 & 652 & 280 & 132 & 315 & 355 & 76 & 0.98 & 1.7 \\
\hline November & 29 & 22 & 7.3 & 2.7 & 650 & 322 & 156 & 320 & 360 & 82 & 1.02 & 1.8 \\
\hline December & 31 & 21 & 7.3 & 2.6 & 664 & 328 & 158 & 325 & 320 & 96 & 1.22 & 1.9 \\
\hline January-2015 & 32 & 21 & 7.3 & 2.6 & 658 & 282 & 162 & 285 & 305 & 84 & 1.28 & 1.9 \\
\hline February & 33 & 23 & 7.4 & 2.6 & 540 & 296 & 158 & 270 & 295 & 72 & 1.66 & 1.8 \\
\hline March & 35 & 23 & 7.5 & 2.5 & 528 & 232 & 132 & 265 & 250 & 78 & 1.26 & 1.6 \\
\hline April & 37 & 23 & 7.5 & 2.3 & 534 & 220 & 132 & 255 & 255 & 68 & 0.66 & 1.5 \\
\hline May & 39 & 23 & 7.5 & 2.3 & 520 & 196 & 120 & 250 & 235 & 64 & 0.68 & 1.6 \\
\hline
\end{tabular}

Table 8. Seasonal average values of arsenic and other heavy metals parameters of shahabad - station 2.

\begin{tabular}{l|l|l|l|l|l|l|l|l|l|l|l}
\hline Seasons/Heavy metals & $\mathrm{Cu}$ & $\mathrm{Fe}$ & $\mathrm{Zn}$ & $\mathrm{Mn}$ & $\mathrm{Cd}$ & $\mathrm{Si}$ & $\mathrm{V}$ & $\mathrm{Ti}$ & $\mathrm{Cr}$ & $\mathrm{Mo}$ & $\mathrm{As}$ \\
\hline SWM & 0.0054 & 0.1104 & 0.016 & 0.022 & 0.025 & 6.80 & 0.66 & 1.67 & 0.088 & 0.130 & 0.02 \\
\hline NEM & 0.058 & 0.1189 & 0.018 & 0.065 & 0.056 & 7.01 & 0.72 & 1.68 & 0.089 & 0.156 & 0.02 \\
\hline SUMMER & 0.0065 & 0.1212 & 0.026 & 0.097 & 0.068 & 8.62 & 0.86 & 1.98 & 0.097 & 0.187 & 0.03 \\
\hline
\end{tabular}

All the physico - chemical parameters of the groundwater Sedam and Shahabad regions of Gulbarga district have been analyzed and presented in the table No. 1 to 8 . The values of four borewells of Sedam region are consolidated (in Table No. 1 to 4) depicting physic-chemical and heavy metals values of the Sedam town. The atmospheric temperature and water temperature are recorded maximum $39^{\circ} \mathrm{C}$ in May and $23^{\circ} \mathrm{C}$ in Summer season. Similarly minimum atmospheric temperature recorded $26{ }^{\circ} \mathrm{C}$ in January and water temperature $22^{\circ} \mathrm{C}$ in Northeast Monson and Southwest Monson Seasons respectively. The pH values were highest 7.3 and 7.4 during the month of December and April and May. Similarly lowest 7.1 and 7.2 in Southwest and Summer monsoon Season respectively. The total hardness, calcium hardness and magnesium hardness values were noticed maximum $652 \mathrm{mg} / \mathrm{l}$., $352 \mathrm{mg} / \mathrm{l}$. and $212 \mathrm{mg} / \mathrm{l}$ in station I and $650 \mathrm{mg} / \mathrm{l}, 250 \mathrm{mg} / \mathrm{l}$ and $150 \mathrm{mg} / \mathrm{l}$ in October Station 2 respectively. The DO values ranged from maximum 2.4mg/l. in October and minimum $1.8 \mathrm{mg} / \mathrm{l}$. in March and May in Station 1 and highest 2.6 $\mathrm{mg} / \mathrm{l}$ in October and lowest $2.1 \mathrm{mg} / \mathrm{l}$ in March in Station II respectively. Likewise, total alkalinity values were highest $425 \mathrm{mg} / \mathrm{l}$. during October and December and lowest $285 \mathrm{mg} / \mathrm{l}$. in May. Phosphate values were much higher $1.15 \mathrm{mg} / \mathrm{l}$. in January and lower $0.60 \mathrm{mg} / \mathrm{l}$. in March in station I likewise in station 2 minimum and maximum values ranged between $68 \mathrm{mg} / \mathrm{l}$ in March and $1.12 \mathrm{mg} / \mathrm{l}$ in January respectively. Similarly, the fluoride values recorded highest $1.6 \mathrm{mg} / \mathrm{l}$. in October and lowest $1.1 \mathrm{mg} / \mathrm{l}$. in April in station 1 and lowest values $1.66 \mathrm{mg} / \mathrm{l}$ in December and $0.8 \mathrm{mg} / \mathrm{l}$ in May.

The heavy metals were analyzed and average values of seasonal results are depicted in Table No. 2. 
The $\mathrm{Cu}$ values of the station-1 recorded highest $0.078 \mathrm{mg} / \mathrm{l}$. during South West Monsoon (SWM) and Northeast Monsoon Season (NEM) and lowest values $0.007 \mathrm{mg} / \mathrm{l}$. recorded during summer. The Fe, Zn and $\mathrm{Cd}$ higher concentrations are noticed maximum $0.21 \mathrm{mg} / \mathrm{l}, 0.018 \mathrm{mg} / \mathrm{l}$ and 0.076 in NEM season and lowest values noticed $0.2 \mathrm{mg} / \mathrm{l}, 0.018 \mathrm{mg} / \mathrm{l}$ and $0.030 \mathrm{mg} / \mathrm{l} \mathrm{SWM}$ respectively. The $\mathrm{Mn}, \mathrm{Si}, \mathrm{V}, \mathrm{Cr}$, Mo and Arsenic concentrations were recorded highest $0.09 \mathrm{mg} / 1,9.12 \mathrm{mg} / 1,0.86 \mathrm{mg} / \mathrm{l}, 0.13,0.210$ and $0.23 \mathrm{mg} / \mathrm{l}$ in Summer Season and lowest values recorded $0.05 \mathrm{mg} / \mathrm{l}, 6.98 \mathrm{mg} / \mathrm{l} 2.02 \mathrm{mg} / \mathrm{l} \& 2.02 \mathrm{mg} / \mathrm{l}$ respectively. The values of $\mathrm{V}$, Mo and As were maximum $0.28 \mathrm{mg} / \mathrm{l}, 0.152 \mathrm{mg} / \mathrm{l}$ and $0.211 \mathrm{mg} / \mathrm{l} \mathrm{in} \mathrm{SWM}$ season and $\mathrm{Si}$, Ti Cr were maximum in $6.98 \mathrm{mg} / \mathrm{l}, 0.02 \mathrm{mg} / \mathrm{l}$ and $0.11 \mathrm{mg} / \mathrm{l} \mathrm{in} \mathrm{NEM}$ season respectively.

The seasonal average values of heavy metals of Sedam station 2 were shown in table 4 . The highest values of $\mathrm{Cu}$ and $\mathrm{Fe}$ recorded highest $0.092 \mathrm{mg} / \mathrm{l}$ and $0.232 \mathrm{mg} / \mathrm{l}$ in NEM season and lowest values noticed $0.008 \mathrm{mg} / \mathrm{l}$ in summer 0.09 during SWM season respectively. The maximum concentrations of the Zn, Mn, Cd, Si, V Cr and Mo recorded $0.036 \mathrm{mg} / \mathrm{l}, 0.09 \mathrm{mg} / \mathrm{l}, 0.12 \mathrm{mg} / \mathrm{l}, 8.12 \mathrm{mg} / \mathrm{l}, 0.88 \mathrm{mg} / \mathrm{l} 0.21$ $\mathrm{mg} / \mathrm{l}$ and $0.20 \mathrm{mg} / \mathrm{l}$ in summer season and lowest concentrations noticed $0.019 \mathrm{mg} / \mathrm{l}, 0.08 \mathrm{mg} / \mathrm{l}, 7.92$ $\mathrm{mg} / \mathrm{l}$, in NEM season and $0.042 \mathrm{mg} / \mathrm{l}, 0.32 \mathrm{mg} / \mathrm{l}, 0.18 \mathrm{mg} / \mathrm{l}$ and 0.16 in SWM season respectively. The As and Ti values ranged highest $0.32 \mathrm{mg} / \mathrm{l}$ and $3.32 \mathrm{mg} / \mathrm{l}$ in SWM season and lowest $0.29 \mathrm{mg} / \mathrm{l}$ and 2.90 $\mathrm{mg} / \mathrm{l}$. summer season.

In the present study both the stations of Shahabad regions the seasonal average values of the Physicochemical parameters are presented in Table No. 5 and Table No. 7 value of the atmospheric temperature and water temperature were highest $39{ }^{\circ} \mathrm{C}$ in may and Atmospheric temperature lowest recorded $26{ }^{\circ} \mathrm{C}$ in the month of September. Water temperature recorded is $21^{\circ} \mathrm{C}$ highest in summer and lowest in winter season throughout the study period. The $\mathrm{pH}$ values maximum are 7.9 and 7.6 in June and minimum 7.3 in both station I and II in December and January respectively. Total hardness maximum and minimum concentrations ranged between $815 \mathrm{mg} / \mathrm{l}$. to $610 \mathrm{mg} / \mathrm{l}$. in December and April in station-I and highest $644 \mathrm{mg} / \mathrm{l}$. in December and lowest $520 \mathrm{mg} / \mathrm{l}$. in May respectively. Calcium hardness recorded maximum $366 \mathrm{mg} / \mathrm{l}$. in November and minimum $272 \mathrm{mg} / \mathrm{l}$. in the months of May and July, similarly in station II recorded $386 \mathrm{mg} / \mathrm{l}$. in December and lowest $186 \mathrm{mg} / \mathrm{l}$. in June respectively. Magnesium hardness noticed highest $214 \mathrm{mg} / \mathrm{l}$. during the month of January and lowest values noticed $123 \mathrm{mg} / \mathrm{l}$. in May in station II in January and 112 in July. Chloride highest and lowest concentrations ranged between $385 \mathrm{mg} / \mathrm{l}$. and $215 \mathrm{mg} / \mathrm{l}$. during the months of October and May respectively, similarly in station II highest value $325 \mathrm{mg}$.l. in December and lowest value $250 \mathrm{mg} / \mathrm{l}$. in May. Total alkalinity and Fluoride concentrations were recorded maximum $495 \mathrm{mg} / \mathrm{l}$. and $1.9 \mathrm{mg} / \mathrm{l}$. in December and minimum $310 \mathrm{mg} / \mathrm{l}$. and $1.5 \mathrm{mg} / \mathrm{l}$. in June respectively, likewise TA recorded $360 \mathrm{mg} / \mathrm{l}$ in November and lowest $235 \mathrm{mg} / \mathrm{l}$. in May, Fluoride $1.9 \mathrm{mg} / \mathrm{l}$. in August and lowest $1.5 \mathrm{mg} / \mathrm{l}$. in April respectively. Phosphate concentrations were recorded maximum $1.68 \mathrm{mg} / \mathrm{l}$. in January and minimum $0.8 \mathrm{mg} / \mathrm{l}$. in June. Similarly 1.66 in February and lowest $0.66 \mathrm{mg} / \mathrm{l}$. April NO3 is highest $110 \mathrm{mg} / \mathrm{l}$. January and lowest $56 \mathrm{mg} / \mathrm{l}$. in August $96 \mathrm{mg} / \mathrm{l}$. in the month of December and lowest $62 \mathrm{mg} / \mathrm{l}$. in August.

\section{Discussion}

The temperature is one of the physical parameters which are directly related with chemical reaction in the water and biochemical reaction in the living organisms. It is very important in determination of solubility of dissolved oxygen $\mathrm{CO}_{2}$ and determination of $\mathrm{pH}$ and conductivity. The higher air and water temperature observed during summer and SWM (South West Monsoon) Season. It must be due to the presence of cloudy weather according to Uyeno (1966). Similar observations are made by Baswaraj et al.,

Alkalinity of the water is its capacity to neutralize a strong and is characterized by the presence of hydroxyl ions capable of combining with hydrogen ion. Most of the alkalinity in heated water is formed due to dissolution of $\mathrm{CO}_{2}$ in water. In the present study higher concentration of alkalinity observed in NEM season and lower values in Summer season. The similar observations are made by Gopal and Bhargav (1982), Tiwari (2001) and Majagi (2008).

Chloride occur naturally in all types of water on natural freshwater, however, most important source of chloride in the waters discharge of domestic waste. In the present investigation chlorides have shown higher concentration during NEM season and lower values recorded in Summer. Mamata Goyal (2006) observed similar findings in some part of Unnao district. It may be due to the increase in the mineral content. 
$\mathrm{NO}_{3}$ Nitrate represents the highest oxidized form of nitrogen. Many of groundwater has significant quantities of nitrates due to leaching of the nitrate with the percolating water. Groundwater can also be contaminated by sewage and other wastes rich in nitrates. Hence, nitrate concentration observed higher values during NEM and lower values during SWM seasons.

$\mathrm{PO}_{4}$ Phosphorus being an important constituent of biological systems, may also be present in the organic form. Some major phosphorus is domestic sewage, detergents, agriculture, effluents and fertilizers (Pandey et al., 1979, Sinha et al., 2000). Higher concentration of $\mathrm{PO}_{4}$ is higher in NEM and lower in summer. According to the water pollution Act, 1997 Regulation, 1998 (SINO.258), in order to prevent eutrophication of surface water, groundwater levels should not exceed $0.03 \mathrm{mg} / \mathrm{L}$ orthophosphate (Robert et al., 1983).

Fluoride is naturally present in water, and it becomes toxic to animal and human beings when present at more than $1 \mathrm{mg} / \mathrm{l}$. concentration in drinking water (Mamata Goyal, 2006). According to WHO the limit of fluoride concentration is $1.5 \mathrm{mg} / \mathrm{l}$, in our study higher values in NEM and lower in summer are due to sedimentary formation of bhima group which is constituted by conglometer, sand stone, shale and lime stone (Ramesh, 2002).

$\mathrm{pH}$ is the measure of the intensity of acidity and alkalinity and measure the concentration of hydrogen ions in water. The $\mathrm{pH}$ of water gets drastically changed with time due to the exposure to air, biological activity and temperature change. Determination of $\mathrm{pH}$ is one of the important objectives in treatment of wastes. In the present study $\mathrm{pH}$ values were higher during NEM season, and similar findings were observed by Aboo et al., (1986), Singh and Shah (1981), Verma et al., (2000), Majagi (2008).

Dissolved oxygen is one of the most important parameters in the water quality assessment and reflects the physical and biological process preventing in the water. The concentration of oxygen will also reflect whether the process undergoing is aerobic or anaerobic. Low oxygen concentrations are generally associated with heavy contamination by organic matter. DO of the study area recorded more during NEM season and less during Summer season. Lower oxygen is generally associated with contamination by organic matter. Similar observations noticed by Jain et al., (2000 (a) \& (b)), Adak and Purohit (2000).

\subsection{Heavy Metal Analysis}

Heavy metals are among one of the pollutants of freshwater which pose severe threats to the biodiversity with the development of aiming smelting and other industrial activities. Some of these metals act as micro nutrients, small concentration in living organisms for their normal physiological activities but accumulation in higher concentration becomes toxic to most life forms (Lasat 2002, cheng, 2003). Seasonal variation of the heavy metals (Cu, Fe, Zn, Mn, Cd, Si, V, Ti, Cr, Mo, Al, As) of Sedam and Shahabad is measured concentration of heavy metals shown drastic difference associated with seasons.

Table 9. Correlation significant at.

\begin{tabular}{l|l}
\hline Parameters & Correlation \\
\hline Atmospheric temperature & Water temperature $\mathrm{P}<0.01$ \\
\hline Water temperature & $\mathrm{PO} 4, \mathrm{P}<0.01, \mathrm{pH}<0.05$ \\
\hline $\mathrm{pH}$ & DO $\mathrm{P}<0.01, \mathrm{NO} 3 \mathrm{P}<0.01$ \\
\hline $\mathrm{DO}$ & Harness, Calcium hardness, NO3 $\mathrm{P}<0.01$, Chloride and Fluoride $\mathrm{P}<0.05$ \\
\hline Hardness & Dissolved oxygen, Alkalinity, $\mathrm{P}<0.01$ \\
\hline $\mathrm{Ca}$ & Magnesium hardness, Alkalinity and fluorideP $<0.01$ and Chloride $\mathrm{P}<0.05$. \\
\hline $\mathrm{Mg}$ & Alkalinity, Chloride $\mathrm{P}<0.01$ Fluoride and $\mathrm{PO} 4 \mathrm{P}<0.05$ \\
\hline Chloride & \\
\hline Alkalinity & NO3 and Fluoride $\mathrm{P}<0.01$ and NO3 $\mathrm{P}<0.05$ \\
\hline NO3 & $\mathrm{PO} 4$ Fluoride $\mathrm{P}<0.01$ \\
\hline $\mathrm{PO} 4$ & Fluoride $\mathrm{P}<0.01$ \\
\hline
\end{tabular}




\section{Conclusion}

1. All the water samples subjected for analysis are found moderate and parameters are within permissible limit found good for human consumption.

2. Sources of pollution are geological factors and percolation of pollution water in the catchment area.

3. Analysis of heavy metals through atomic absorption spectrophotometer was done and presented in table no. 2, 4, 6 and 8 . All the values are found with in permissible limit.

Acknowledgements. I Sincerely Thank UGC, SWRO Bangalore for funding to carry out the Minor Research Project.

I also thank USIC Gulbarga University , Kalaburagi for providing facility for heavy metal s analysis.

\section{References}

1. K. M. Aboo, C. A. Sastry, and P. G. Alex. A study well waters in Bhopal city, Environmental health. 10, 189203. 1986.

2. D. M. Adak and K. M. Purohit. Correlation co-efficient of some physic-chemical characterstics of surface and groundwaters of Rajgangapur Part-I Indian Journal of Environmental protection 20 (9) 681-687. 2000.

3. C. Baswaraj, S. Manjunath, S Raju. and B. Chandankumar. Evaluation of groundwater quality in Chintamani Taluk, Chikkballapur district, Karnataka, India. International Research Journal of Earth Sciences. Vol. 4(2) 1522. 2016.

4. W. R.Cullen, and K. J. Reimer: Chem Rev. 89, 713. 1989

5. Danish veterinary and Food administration. Danish Fresh water fish contents of trace elements, PCB and Chlorinated pesticides publication No. 138. Soborg. 1986.

6. Department of Health, report on health and social subjects 41. London. 199.

7. J. G. Farmer, and L. R. Johnson: Env. Geochem. Health, 7, 124. 1985.

8. Food and Agriculture organization (FAO). World Health Organization (WHO), WHO Food Addit. Ser., No.18. 1983.

9. Food and Agriculture organization (FAO). World Health Organization (WHO), WHO Food Addit. Ser., No.24. 1983

10.R. Gopal, and T. N. Bhargava, Quality of groundwater in the arid district of Rajasthan I. IWWA XIV (2) 157 163. 1982.

11.IARC. Monographs, Suppl. 7, 100-106. 1987.

12.C. K. Jain, K. K. S. Bhatia, and Vijaykumar, Groundwater quality in sagar district, Madhya Pradesh. Indian journal of Environmental health 42(4), 151-158. 2000b.

13.I. K. Jain, K. K.S. Bhatia, and S. R. Kumar, Groundwater contamination in greater Guwahati, Assam. Indian Journal of Environmental Protection 20(9), 641-648. 2000a.

14.G.Mamta, D N. Dhar, and D. C. Rupainwar, An assessment of groundwater pollution and its chemical quality in same parts of Unnao district. Indian Journal Environmental protection, 26(2) 116-124. 2006.

15.S. P. Pandey, V. S. NarayanSwamy, and M. Z. Hasan,. Quality of well waters of Nagpur with regard to nitrates. Indian Journal of Environmental Health, 21, 35-46,1979 .

16.M. Shashikanth, K. Vijaykumar, M. Rajashekhar. and B. Vasanthkumar,. Chemistry of groundwater in Gulbarga district, Karnataka, India. Environment monitoring and Assessment 138: 347-354. 2008.

17.N. K. Singh, and L.C. Shah, Diurnal cycle of abiotic parameters at Ramsar Well, Bhagapur comp. Physio.Eco. 4 (1) 38-40. 1981.

18.A. K.Sinha, K. P. Srivastava, and J. Sexena, Impact of urbanization on groundwater of Jaipur, Rajasthan earth resources and environmental issues. 2000.

19.D. R.Tiwari, Hydrogeochemistry of underground water in around Chatarpur city district, Chatarpur ( M.P.). Indian Journal of Environmental health, 43 (4) 176. 2001.

20. Toxicological profile for arsenic U.S. Department of Health and Human Services, Agency for substances and disease registry , Atlanta. 1991 
21.United States Environmental Protection Agency 1988. Special report on ingested inorganic Arsenic. Skin cancer, Nutritional Essentiality, EPA-625/3-87-013, Washington, DC.

22.E. O. Uthus, , Environmental Geochemistry and Health, 14, 55. 1992.

23.F. Uyeno, Nutrient and energy cycle in an esturine oyster area M. P. Proceedings of the National Academy of Sciences India. 52 (B) IV-189. 1966.

24.N. E. M. Verma, P. Vishal, D.C. Yadav' and P. Prabhat, Study of quality of groundwaters of some villages Shikhohabad, District Firozabad (India) Asian Journal of Chemistry. 12 (2) 458-462. 2000.

25.World Health Organization (WHO). Arsenic; Environmental Health criteria 18. Geneva. 1981.

26.World Health Organization (WHO). Guidelines for drinking water quality Geneva. 1993. 